\title{
Unethical Behavior of the Students of the Czech University of Life Sciences
}

\author{
Ludmila Dömeová ${ }^{1} \&$ Andrea Jindrová ${ }^{2}$ \\ ${ }^{1}$ Department of Systems Engineering, Faculty of Economics and Management, Czech University of Life \\ Sciences Prague, Czech Republic \\ ${ }^{2}$ Department of Statistics, Faculty of Economics and Management, Czech University of Life Sciences Prague, \\ Czech Republic \\ Correspondence: Ludmila Dömeová, Faculty of Economics and Management, Czech University of Life Sciences \\ Prague, Kamýcká 129, Prague 16521, Czech Republic. Tel: 420-224-382-181. E-mail: domeova@pef.czu.cz
}

Received: August 26, 2013 Accepted: September 27, 2013 Online Published: October 16, 2013

doi:10.5539/ies.v6n11p77 URL: http://dx.doi.org/10.5539/ies.v6n11p77

The research is financed by the Faculty of Economic and Management, Czech University of Life Sciences in Prague, via IGA grant, no. 11170/1312/3164.

\begin{abstract}
The cheating can be viewed as a major educational problem with a broad social concern. The unethical behaviour of students can crucially influence their qualification, future employment and manners in their professional carrier. The contribution investigates the unethical behaviour of the students of the University of Life Sciences in Prague. The goal is to examine if the students would act unethically in an examination tests and in proceeding their assignments. The inquiry investigation based on self-assessments confirmed that the unethical behaviour is quite frequent, more frequent is the exam cheating. The responders do not feel that their behaviour is immoral, they are rather afraid of penalization. The reaction of the teachers and the university is necessary. It is essential to study the reasons of unethical behaviour to apply rectifying measures effectively.
\end{abstract}

Keywords: unethical behaviour, university students, exam cheating behaviours, assignment cheating behaviour

\section{Introduction}

The unethical behaviour, exam cheating, and illegal collaboration on assignments including plagiarism are very frequent (Center for Academic Integrity, 1999 ). It is important to deal with the methods and frequency of such behaviour and also with the way it is perceived by the academia.

The cheating during the studies leads to the disarray of the goals of the study. The students will not acquire the intended knowledge and skills, further more they adopt inappropriate working methods and immoral attitude to their duties. It is important for lecturers to show students how to establish their own effective learning strategies (Nguyen, 2010).

The students continue to apply the improper working procedures in their future jobs what can cause the real economical damages as well as an injury of the employees' reputation (Smith et al., 2002).

The students' attitude to the study influences also the evaluation of the courses, teachers and the whole faculties and universities. It was proved (Jindrová et. al, 2013) that the students with a procrastinating attitude to the study duties are much more critical towards the teachers, the study materials, etc.

The university's good name, reputation and competitiveness might be influenced as well. If the unethical behaviour is not systematically and persistently chased and penalized, the university can gain a reputation of a place where everybody obtains certificate without work. The goal-directed students with good study potential are then not interested in such an institution. Finally, the immoral behaviour of the students harms the work of the teachers and managers of the school. 


\subsection{Ethics}

The ethics is a philosophical science which tries to define an optimal and adequate behaviour of people. As a discipline, it is concerned about what in our action is moral and immoral, good and bad, acceptable and unacceptable (Colnerud, 1997; Dika \& Hamiti, 2011).

The ethics deals with theoretical investigation of values and principles which determines the human behaviour in situation of possible choice by one's free will. The ethics tries to find the general fundamental of the moral which is closer to concrete rules (Thompson, 2004).

The ethic behaviour at schools is a frequently discussed topic especially in connection with an exploitation of the new information and communication channels. The ethics in use of learning technology, especially of computers, is now an important issue for practitioners and policy makers (Beycioglu, 2009). While information and communications technology has become an essentials learning tool, an unethical use of it may also be found to be a problem (Jung, 2009). The cheating is a part of more variety of problems connected with the on-line safety (Chou \& Peng, 2011).

There have been many theories and schools with different access to solution of the basic problems. These theories show that there can be a number of controvert meanings and that the ethical problems are highly complicated and sensitive.

\subsection{Unethical Behaviour of the University Students}

The ethical access to study duties is an important precondition for the university studies. The good relations among the faculty members, students, and the whole society, should be based on honour and good manners (Čipáková, 2005).

The ethical principles are often violated by the university students. The Centre for Academic Integrity (CAI), has found that more than $75 \%$ of college students cheat at least once during their undergraduate careers.

The CAI defines academic integrity as a commitment, even in the face of adversity, to five fundamental values: honesty, trust, fairness, respect, and responsibility. From these values flow principles of behaviour that enable academic communities to translate ideals into action (Center for Academic Integrity, 1999).

To describe a violation of academic integrity, the terms 'academic dishonesty,' 'academic cheating,' and academic misconduct' are used interchangeably, although 'dishonesty' refers to an abstract concept whereas 'cheating' and 'misconduct' refer to behaviour. The term 'cheating' is more often used in relation to examinations, and the other unethical behaviours are called 'academic misconduct' (McCrink, 2010).

The most frequent is probably plagiarism. In such a case the authors present a work of another person as their own (Čipáková, 2005).

The other severe unethical activities by Park et al. (2013) are:

- Studied exam questions collected from old exams without the instructor's knowledge.

- Participated in collecting exam questions as a group for other students.

- Provided your paper to another student although you know he/she would copy it.

- Collaborated on an assignment when the instructor asked for individual work.

It is not easy to predict the misconduct behaviour. By some authors the important factors that distinguish the students' attitude towards the unethical behaviour are sex, school grade, self-restraint, and tolerance of deviance (Jensen et. al., 2002). In other cases the search for the demographic predictors of cheating has proved to be disappointing (Nathanson et al., 2006).

\subsection{Results of Study and Dealing with the Unethical Behaviour}

Findings have shown that students who report comparatively high levels of cheating have lower grade point averages (Graham et al., 1994 in Jensen et al., 2002) and IQ scores (Kelly \& Worrell, 1978 in Jensen 2002 et al.). Among college students, there is direct evidence that cheating is inversely related to one's self-reported ability to insure a successful outcome (Murdock et al., 2001). Low scores on scholastic ability appear to predispose students to cheat (Nathanson et al., 2006). The mentioned studies showed that the students who are not able to reach good grades with fair methods use cheating. Even though it does not help and they still have worse results than the others.

Cheating not only results in biased assignment of grades, it also interferes with teachers' ability to use assessment as a mechanism for monitoring and modifying instruction (Murdock et al., 2001). 
The competition can also influence the cheating. Subjects who know that they cannot perform very well in comparison to the people they are competing against may find it necessary to make use of illegitimate tactics to retain some chances to succeed (Schwieren, 2012).

Between cheating in schools and professional behaviour in the workplace is a close relationship (Khodaie, 2011). The moral behaviour of students in college today is likely to carry to the workplace in the future (Abu Bacar et al., 2010).

It is clear that the teachers and the school cannot ignore the unethical behaviour. If cheating is not dealt with successfully, more students will seek unfair means to obtain high scores, not trust each other, and feel they are being victimized or disadvantaged. The most important intervention are fair responses of university, followed by increased surveillance in the testing area (Park et al., 2013).

Roberts-Cady (2008) described two basic approaches to rectifying the problem of examination cheating: behaviour modification strategies through such measures as tighter invigilation and harsher penalties, and character development strategies such as through "honour codes". Smith et al. (2002) suggests that educators target students for formal and/or informal tutorial programs (e.g. those seeking assistance and/or those with low initial test scores), as a means to reduce the students' perceived need to cheat to succeed. Another approach may be to reduce the degree of competitiveness among the students (Nathanson, 2010).

\subsection{Continuity with Previous Research}

The authors' previous work (Jindrová et al., 2013) deals with the evaluation of some courses in the University of Life Sciences in Prague and the e-support of the students. The dependencies between the discipline of the student (self evaluation) and the rating of the e-support were proved. The access to the duties distorted the evaluation of the courses insofar that the responders had to be spitted into two groups: "more disciplined" and "less disciplined".

The detailed analysis found that these less disciplined student are more demanding of better e-support, they see the teachers less qualified and call for more and better materials and faster answers from teachers.

It follows from the previous work that it is necessary to count with the possibility of various types of unethical behaviour of the students when evaluating the courses, teachers, etc.

\subsection{Goal of Present Investigation}

This study deals with the various way of unethical behaviour of the undergraduate students of the University of Life Sciences in Prague. The research is based on an inquiry investigation where the students self-evaluated their behaviour and their approach to the study duties. The responders of the survey were the students of the Czech University of Life Sciences in Prague. The subsequent analysis searched for the relations between the gender (resp. the year of study) and the unethical behaviour.

The basic question of the research was: „How often and in which situations the university students do not act in line with honour and good manners in their study duties?"

The partial goals of this study focus on:

- Exam cheating behaviours.

- Assignment cheating behaviours.

- Attitude to unethical behaviour and consecutive sanctions.

For meeting the objectives of the study following working hypotheses were used:

$\mathrm{H}_{1}$ : The students are trying to achieve the best possible results at all costs.

$\mathrm{H}_{2}$ : The students perceive and evaluate the unethical behaviour negatively.

$\mathrm{H}_{3}$ : The gender has no influence on the ethical judgement (behaviour) of the student.

$\mathrm{H}_{4}$ : The year of study has no influence on the ethical judgment (behavior) of the student.

\section{Research Methodology}

\subsection{Participants}

The participant subjects in our study were the second year students of Business Administration and the fifth year students of Economics and Management at the Czech University of Life Sciences, Faculty of Economics and Management. The inquiry investigation was realized during the summer semester 2012 . The complete anonymity of the respondents was assured. A total of 427 usable responses were received, 169 from men (39.6\%) and 258 
from women (60.4\%). 269 (63\%) respondents were from the second year and $158(37 \%)$ were from the fifth year.

\subsection{Survey Instrument}

The creation of the survey instrument (questionnaire) used in this study was based on comparison of available materials dealing with similar topics. Three groups of closed questions were used. The closed questions offered three variants of answers. The responder had to choose just one answer to each question.

The first part focused the unethical behaviour at the written tests; the second part dealt with writing the semester projects, bachelors and diploma thesis; the third part is intended to seek the students' attitudes towards the unethical behaviour and the sanctions.

The questionnaire also contained the demographic characteristics of the participants.

\subsection{Applied Statistical Methods}

The data proceeding was realized in several consecutive phases. First, the check of complete fulfilment was made. Second, the answers were codified and the data were transformed into numbers. The single dimensional and multi dimensional statistical analyses followed.

The single dimensional statistical analysis was based on the relative frequency tables. The frequency distribution gives a schematic overview of the established values; presented as a frequency distribution table.

The values $n_{j}$ in the frequency distribution tables are the absolute values of the incidences of the observed sign values. The relative frequencies $p_{i}$ represents the proportion of the concrete sign values to the total extent of the file.

The multiple dimensional analysis was based on the Cramer's contingency coefficient which can have values from the interval $<0 ; 1>$. The value 0 means total statistical independence of variables, the value under 0.3 means weak dependence, 0.3-0.5 medium dependence, 0.5-0.7 high dependence, over 0.7 means very high dependence.

For the chí square test and the following analysis the significance level $\alpha=0.05$ was used. The practical calculations were made with MS Excel and the statistical software SPSS version 20.

\section{Results and Discussion}

\subsection{Simple Analysis}

The first part of the questionnaire investigated the behaviour of the students at the examination or the midterm tests. The results are in Table 1.

The unauthorized notes, copying or prompting was described most frequently as exceptional but used. Rarely used way of cheating is an exploitation of electronic devices (as mobile phones). $91.3 \%$ of responders stated that they never use this way of cheating, only $2.6 \%$ answered that they use it often.

The students quite often try what is possible in the concrete subject, with the concrete teacher. Many students use information from their colleges who have already passed the test (77.4\%).

The question is if such behaviour is really unethical. To get the test including correct answers is definitely unethical but there are many cases "in between". The students can get some questions, the correctness of the answers is not guaranteed, etc. The sample tests and lists of examination question are often public and the information from other students are not so valuable.

Table 1. The behaviour of student in tests $(\%)$

\begin{tabular}{llll}
\hline Question & Never & Exceptionally & Often \\
\hline Do you use unauthorized notes (cribs) or other aids? & 17.1 & 74.0 & 8.9 \\
Do you use (copy) other students' answers? & 19.2 & 71.1 & 9.6 \\
Do you communicate with other students (prompt)? & 16.0 & 63.7 & 20.3 \\
Do you use electronic device (mobile phone)? & 91.3 & 6.1 & 2.6 \\
Do you use information from students who have passed the test? & 6.0 & 16.7 & 77.4 \\
Do you modify or exchange the test instruction form? & 59.0 & 26.1 & 14.9 \\
\hline
\end{tabular}


The second part of the questionnaire deal with the unethical behaviour in working on term papers and assignments, bachelor and diploma thesis.

(The Hong Kong Polytechnic University: About plagiarism and how to avoid it: Hot tips for PolyU students, 2008, p. 2 in Li \& Casanave, 2012): "Plagiarism is passing off someone else's work or ideas as your own to gain some benefit. For students, 'benefit' may mean trying to get a better grade or mark, or meeting a deadline so marks are not lost."

The copying without mentioning the source is often used by $3.3 \%$ and exceptionally by $21.9 \%$ of students. The Internet is used for plagiarism exceptionally by $39 \%$ and often by $11 \%$ of students. One text submitted in more subjects is used exceptionally by $18.5 \%$ of students (see Table 2 ).

The cheating at exams (tests) is more frequent than the unethical behaviour in writing assessments. It means the students are eager to fend off an immediate cause of failure.

The results in Table 1 and Table 2 did not prove responsible approach of students but demonstrate that they prefer getting good grade, credit or graduation.

The working hypothesis $\mathrm{H}_{1}$ : The students are trying to achieve the best possible results for any price can be confirmed.

The reason usually given by students was too many tasks which cannot be properly elaborated within the given time. Many of them did not realize that the demands are in line with the goals of the university study.

Koul et al. (2009) found that performance oriented students were more strict about what they consider to be plagiarism, and males were stricter than females.

A coping strategy commonly used by novice writers who are unfamiliar with the subject matter is "patchwriting", which has been characterized as "copying from a source text and then deleting some words, altering grammatical structures, or plugging in one-for-one synonym substitutes (Howard, 1993). The Internet made textual borrowing strategies easier but it has also made detection of copied material easier ( $\mathrm{Li} \&$ Casanave, 2012).

Many institutions (including Czech University of Life Sciences and other Czech universities) have focused on mechanical detection of copied materials using specialized software but the ,pathwriting“ can be quite often undetected. Howard (2007) remarks that the mechanized applications offered by plagiarism-checking services may make some reduction in the incidence of readily detectable plagiarism but do not indicate differences between bungling citations and downloading term papers.

Table 2. The behaviour of students in writing assignments (\%)

\begin{tabular}{|c|c|c|c|}
\hline Question & Never & Exceptionally & Often \\
\hline $\begin{array}{l}\text { Do you copy other persons' texts in your midterm projects, bachelor's or } \\
\text { diploma theses without station of the source? }\end{array}$ & 74.8 & 21.9 & 3.3 \\
\hline Do you use not existing sources and fabricated data in your works? & 87.5 & 10.1 & 2.4 \\
\hline Do you let another person to do your work? & 88.5 & 10.1 & 1.4 \\
\hline $\begin{array}{l}\text { Do you use Internet or other sources for downloading the works of } \\
\text { someone else? }\end{array}$ & 50.0 & 39.0 & 11.0 \\
\hline $\begin{array}{l}\text { Do you resubmit a paper that was submitted in another course, without } \\
\text { major adjustment? }\end{array}$ & 80.3 & 18.5 & 1.2 \\
\hline
\end{tabular}

The last part of the questionnaire is intended to seek students' attitudes towards the unethical behaviour and the risk of being caught and penalized. The results in Table 3 say that $34 \%$ of responders believe that the school has enough instruments to prevent the cheating, $22 \%$ thing that there are not enough instruments, and $44 \%$ do not know if the schools has any instrument which could be barriers to the unethical behaviour. The results also show that we meet the ethical dilemmas in the university environment quite often.

$66.4 \%$ of responder feels pangs of conscience when they are cheating. It means that the unethical behaviour is not impossible for them even though they are aware of some moral principles.

Based on mentioned results, the working hypothesis $\mathrm{H}_{2}$ : The students perceive and evaluate the unethical behaviour negatively can be confirmed. 
Table 3. Students' attitudes towards the unethical behaviour (\%)

\begin{tabular}{lrrr}
\hline Question & Yes & No & Do not know \\
\hline $\begin{array}{l}\text { Do you thing that your school has enough instruments to prevent the } \\
\text { cheating? }\end{array}$ & 34.0 & 22.0 & 44.0 \\
$\begin{array}{l}\text { Is there any threat of penalty in case of unethical behaviour? Are you } \\
\text { afraid? }\end{array}$ & 76.0 & 10.8 & 13.2 \\
Do you think that the unethical behaviour is frequent at your school? & 31.5 & 27.2 & 41.3 \\
Do you feel pangs of conscience when cheating? & 66.5 & 33.5 &
\end{tabular}

Longitudinal research in school environments reported an increase in cheating over the last decades, and a decrease in individuals' perceived severity of dishonest behaviour (Murdock, et al., 2001).

\subsection{Dependency Analysis}

The following part of the study deals with the analysis of relations between chosen indicators. The goal is to confirm of refuse the $\mathrm{H}_{3}$ and $\mathrm{H}_{4}$ hypotheses. The tests of dependency were made between the identification data (gender, year of study) and responses connected with the ethical behaviour and moral judgement.

Table 4. Proved dependencies of the unethical behaviour or moral judgement and gender

\begin{tabular}{lll}
\hline Question & $\mathrm{p}$-value & $\begin{array}{l}\text { Cramer's } \\
\text { contingency } \\
\text { coefficient }\end{array}$ \\
\hline Do you use unauthorized notes (cribs) or other aids? & $\mathrm{p}=0.013$ & 0.143 \\
Do you use (copy) other students' answers? & $\mathrm{p}=0.005$ & 0.159 \\
Do you use electronic device (mobile phone)? & $\mathrm{p}=0.009$ & 0.149 \\
Do you hand in one text without major adjustment in more than one subject? & $\mathrm{p}=0.048$ & 0.119 \\
Do you think that the unethical behaviour is frequent at your school? & $\mathrm{p}=0.008$ & 0.150 \\
Do you feel pangs of conscience when cheating? & $\mathrm{p}=0.033$ & 0.103 \\
\hline
\end{tabular}

It follows from the Table 4 that the gender has some influence to the moral judgement of the students. The dependency was proved for 6 questions out of total 15 questions. The dependency was always weak (see the values of the Cramer's coefficient). The more detailed analysis documented that the women are generally more responsible and respect more the ethical rules. The hypothesis $\mathrm{H}_{3}$ : The gender has no influence on the moral judgement (behaviour) of the student was refused.

Gender differences are the most frequent individual attributes tested in the empirical ethical research but the results are ambiguous.

Our results are generally in line with many studies which reported that females are ethically more conservative and are concerned more about ethical issues and business ethics, thus arguably reflecting a higher moral development and thus, moral standards (Ruegger \& King, 1992 in Abu Bakar et. al., 2010). On the other hand the competition induces women to cheat more while there is not a significant effect for men (in the task where women on average performed worse than men the women) (Schwieren, 2012). The women's ethical feeling raises in the risk of getting caught (Abu Bakar, 2010). Nathanson et al., (2006) found no significant differences in cheating rates on any of the demographic variables including the gender. 
Table 5. Proved dependencies of the unethical behaviour or moral judgement and the year of study

\begin{tabular}{lll}
\hline Question & $\mathrm{p}$-value & $\begin{array}{l}\text { Cramer's } \\
\text { contingency } \\
\text { coefficient }\end{array}$ \\
\hline Do you use (copy) other students' answers? & $\mathrm{p}=0.001$ & 0.181 \\
Do you communicate with other students (prompt)? & $\mathrm{p}=0.003$ & 0.169 \\
Do you use electronic device (mobile phone)? & $\mathrm{p}=0.015$ & 0.140 \\
Do you use information from students who passed the test? & $\mathrm{p}=0.006$ & 0.156 \\
Is there any threat of penalty in case of unethical behaviour? Are you afraid? & $\mathrm{p}=0.003$ & 0.164 \\
\hline
\end{tabular}

The last hypotheses $\mathrm{H}_{4}$ focuses on the relation between the year of study and the ethical behaviour. The dependency was proved for 5 questions (see Table 5). The dependency was not strong ( $p$ values $0.140-0.181$ ) similarly to the dependency on the gender but the dependencies were observed for different questions. The detailed analyses indicated that the students of the higher year are more responsible. The students of the fifth year are over their 23 , more grown-up t people, often they already have jobs. They better realize the moral value and they are more afraid of not completing the university studies. The hypothesis $\mathrm{H}_{4}$ : The year of study has no influence on the moral judgement (behaviour) of the student has been refused.

Many possible factors, e.g. personality predictors, which can influence the cheating behaviour, were not investigated in this study. By (Farnese, 2010) the most important are self-efficacy beliefs, colleagues' cheating behaviours, and the moral disengagement. The most probable cheaters are those low in scholastic competence and high in subclinical psychopathic (Nathanson, 2010). The faculty ethical behaviours as fair assessment and clear information on applied rules are vital for students (Ozcan et al., 2013).

Even though this study proved dependencies on gender and the year of study, other factors should be taken into consideration in the future research.

\section{Conclusion}

The results of the investigation have confirmed that majority of student try to reach the best results without own intensive and regular work. Despite they are mostly aware of incorrectness of their behaviour they use some type (possibly even more than one) of cheating to get some benefit usually better grade.

Quite a big part of students (66.4\%) stated that they are afraid of possible resulting penalty and that they know that the possibility of a penalty exists.

The study proved that the female students and the students of the higher year have higher respect to the rules or at least higher respect to possible penalties.

The ethical and unethical behaviour is a problem consisting of many individual properties and predispositions. Not everybody is able to evaluate correctly his or her abilities and capacities and to become reconcile that the university studies are too hard for them. On the other hand the cheating may be just a way to get the graduation with minimum effort.

By our view, this is the point which the university must respond to. It is necessary to determine the students' duties, to pinpoint what is allowed and what is not and, in the same time, define the penalties and sanctions.

The management of the Czech university of Life Sciences in Prague perceives the problem as important and has reacted by conception of a document "Ethical Code for Students and Teachers" which will be valid since next year. The goal is to improve the ethical behaviour of all academics (both students and teachers) and the reputation of the university. The harsher penalties, consistent supervision, and eventually another directive measures can be also recommended because the reasons of cheating are different and the ethical appeal will not be functional in all cases.

\section{References}

Abu Bakar, N., Suhaiza, I., \& Suhaiza, M. (2010). Will Graduating Year Accountancy Students Cheat in Examination? A Malaysian Case. International Education Studies, 3(3), 145-152. 
Beycioglu, K. (2009). A cyberphilosophical issue in education: Unethical computer using behaviour - The case of prospective teachers. Computers \& Education, 53(2), 201-208. http://dx.doi.org/10.1016/j.compedu.2009.01.009

Center for Academic Integrity. (1999). The fundamental values of academic integrity [Electronic Version]. Retrieved from http://www.academicintegrity.org/icai/assets/FVProject.pdf

Chou, C., \& Peng, H. (2011). Promoting awareness of Internet safety in Taiwan in-service teacher education: A ten-year experience. The Internet and Higher Education, 14(1), 44-53. http://dx.doi.org.infozdroje.czu.cz/10.1016/j.iheduc.2010.03.006

Čipáková, J. (2005). Etika: základni etické předpoklady a formy chování v pracovním a společenském styku. Brno: Sting.

Colnerud, G. (1997). Ethical conflicts in teaching. Teaching and Teacher Education, 13(6), 627-635. http://dx.doi.org/10.1016/S0742-051X(97)80005-4

Dika, A., \& Hamiti, M. (2011). Challenges of implementing the ethics through the use of information technologies in the university. WCES-2011. Procedia social and behavioral sciences, 15, 1110-1114. http://dx.doi.org/10.1016/j.sbspro.2011.03.247

Farnese, M. L., Tramontano, C., Fida, R., \& Paciello, M. (2011). Cheating Behaviors in Academic Context: Does Academic Moral Disengagement Matter? Procedia - Social and Behavioral Sciences, 29(20), 356-365. http://dx.doi:10.1016/j.sbspro.2011.11.250

Howard, R. M. (1993). A plagiarism pentimento. Journal of Teaching Writing, 11(3), 233-245.

Howard, R. M. (2007). Understanding "Internet plagiarism". Computers and Composition, 24, 3-15. http://dx.doi.org/10.1016/j.compcom.2006.12.005

Jensen, A. L., Feldman, S. S., Arnett, J. J., \& Cauffman, E. (2002). It's Wrong, But Everybody Does It: Academic Dishonesty among High School and College Students. Contemporary Educational Psychology, 27, 209-228. Retrieved from http://www.idealibrary.com. http://dx.doi.org/10.1006/ceps.2001.1088

Jindrová, A., Vostrá Vydrová, H., \& Dömeová, L. (2013). The students' evaluation of the e-support in the full time form of study. Journal on Efficiency and Responsibility in Education and Science, 6(2), 119-133. http://dx.doi.org/10.7160/eriesj.2013.060205

Jung, I. (2009). Ethical judgements and behaviour: Applying a multidimensional ethics scale to measuring ICT ethics of college students. Computers \& Education, 53(3), 940-949. http://dx.doi.org/10.1016/j.compedu.2009.05.011

Khodaie, E., Moghadamzadeh, A., \& Salehi, K. (2011). Factors Affecting the Probability of Academic Cheating School Students in Tehran. Procedia - Social and Behavioral Sciences, 29, 1587-1595. http://dx.doi.org/10.1016/j.sbspro.2011.11.401

Koul, R., Clariana, R. B., \& Jitgarun, K. (2009). The influence of achievement goal orientation on plagiarism. Learning and Individual Differences, 19, 506-512. http://dx.doi.org/10.1016/j.lindif.2009.05.005

Li, Y., \& Casanave, C. P. (2012) Two first-year students' strategies for writing from sources: Patchwriting or plagiarism? Journal of Second Language Writing, 21(2), 165-180. http://dx.doi.org.infozdroje.czu.cz/10.1016/j.jslw.2012.03.002

McCrink, A. (2010). Academic misconduct in nursing students: Behaviors, attitudes, rationalizations, and cultural identity. Journal of Nursing Education, 49(11), 653-659. http://dx.doi.org/10.3928/01484834-20100831-03

Murdock, T. B., Natalie, M., Hale, N. M., \& Weber, M. J. (2001). Predictors of Cheating among Early Adolescents:Academic and Social Motivations. Contemporary Educational Psychology, 26, 96-115. Retrieved from http://www.idealibrary.com. http://dx.doi.org/10.1006/ceps.2000.1046

Nathanson, C., Paulhus, D. L., \& Williams, K. M. (2006). Predictors of a behavioral measure of scholastic cheating: Personality and competence but not demographics. Contemporary Educational Psychology, 31(1), 97-122. http://dx.doi.org/10.1016/j.cedpsych.2005.03.001

Nguyen, H. C. (2010). The Changing Postmodern University. International Education Studies, 3(3), 88-99. 
Ozcan, K., Aydin Balyer, A., \& Servi, T. (2013). Faculty Members' Ethical Behaviors: A Survey Based on Students' Perceptions at Universities in Turkey. International Education Studies, 6(3), 129-142. http://dx.doi.org/10.5539/ies.v6n3p129

Park E. J., Park S., \& Jang I. S. (2013). Academic cheating among nursing students. Nurse Education Today, 33(4), 346-352. http://dx.doi.org/10.1016/j.nedt.2012.12.015

Roberts, Cady, S. (2008). The role of critical thinking in academic dishonesty policies. International Journal for Educational Integrity, 4(2), 60-66.

Schwieren, C., \& Weichselbaumer, D. (2012). Does competition enhance performance or cheating? A laboratory experiment. Journal of Economic Psychology, 31(3), 241-253. http://dx.doi.org/10.1016/j.joep.2009.02.005

Smith, K. J., Davy, J. A., Rosenberg, D. L., \& Haight G. T. (2002). A structural modeling investigation of the influence of demographic and attitudinal factors and in-class deterrents on cheating behavior among accounting majors. Journal of Accounting Education, 20, 45-65. http://dx.doi.org/10.1016/S0748-5751(01)00026-4

Thompson, M. (2004). Přehled etiky. Praha: Portál.

\section{Copyrights}

Copyright for this article is retained by the author(s), with first publication rights granted to the journal.

This is an open-access article distributed under the terms and conditions of the Creative Commons Attribution license (http://creativecommons.org/licenses/by/3.0/). 